\title{
Performance measurement using balanced scorecard: A case study of pipe industry
}

\author{
Abolfazl Danaei $^{\mathrm{a}}$ and Amer Hosseini ${ }^{\mathrm{b}}$
}

${ }^{a}$ Department of management, Semnan branch, Islamic Azad University, Semnan, Iran

${ }^{b}$ Department of Industrial management, Semnan branch, Islamic Azad University, Semnan, Iran

C H R O N I C L E

\section{Article history:}

Received January 5, 2013

Received in revised format

4 April 2013

Accepted 5 April 2013

Available online

April 52013

Keywords:

Balanced score card (BSC)

Performance measurement

Pipe industry

\section{Introduction}

Balance scorecard (BSC) methodology is considered as an extensive strategic planning system, which has become popular among managers and business owners. BSC is a management system, which helps organizations clearly specify their objectives and strategies based on different characteristics within the organization (Olson \& Slater, 2002). Kaplan and Norton (1992) are believed to be first who introduced the idea of BSC. They implemented BSC as a performance evaluation system for 12 firms in USA in 1992. The primary objective of BSC is to replace and make the necessary changes on traditional performance evaluation techniques, which only focused on financial indexes to calculate more complete and effective evaluation of organizational performance. Despite the fact that financial figures are only part of BSC model, they are still considered as the most important aspects of organizational performance evaluation in BSC. Nevertheless, other perspectives of traditional model

*Corresponding author. Tel: +989302513169

E-mail addresses: Amer_hosseini@yahoo.com (A. Hosseini)

(C) 2013 Growing Science Ltd. All rights reserved.

doi: $10.5267 /$ j.msl.2013.04.004 
such as customer, internal business processes and employee's growth and learning are also needed to be considered, so that performance evaluation model could find a balance among various BSC figures. These aspects are necessary for perception and implementation of a perfect performance measurement systems and formation of a general set of organization performance indexes for strategic investigation of all objectives and activities within organizations (Huang, 2009; Huang et al., 2011). BSC includes four perspectives, which are summarized as follow,

1. Financial aspect: this perspective considers how organizations benefit from their strategic activities.

2. Customer aspect: this perspective pays more attention to the issue, which organizations should benefit of their inherent and available resources for the distinction among their competitors.

3. Internal business process aspect: This includes all strategic activities within an organization to satisfy stockholder and customer's expectations. General process is initiated by perception of customer's requirements and operational as well as sale's figures.

4. Growth and learning aspect: Any organizations wishes to retain permanent activity and development should rely on constant growth and innovation.

According to Kaplan and Norton (1996a, 1996b), organizations have to concentrate on some principals such as promotion of employee's abilities, information system performance, persuasion, etc. This aspect includes three main criteria including employee satisfaction, employee continuity and efficiency. Any business unit needs to create performance evaluation indexes by four BSC criteria and performance indexes have to be chosen based on some measurable figures. Index selection plays an essential role for investigating the required industry performance, since we may enhance efficiency of manufacturing operations and create significant advantages by accurate investigation of these indexes. Performance key indexes should be considered very carefully for achievement of strategic objectives in every four aspects of BSC (Wu et al., 2011). These relationships point to the dependence among financial and nonfinancial indexes. A structured BSC method should include mutual relationships among various aspects and measuring indexes of these aspects (Wang et al., 2010). Fig. 1 shows details of BSC perspectives.

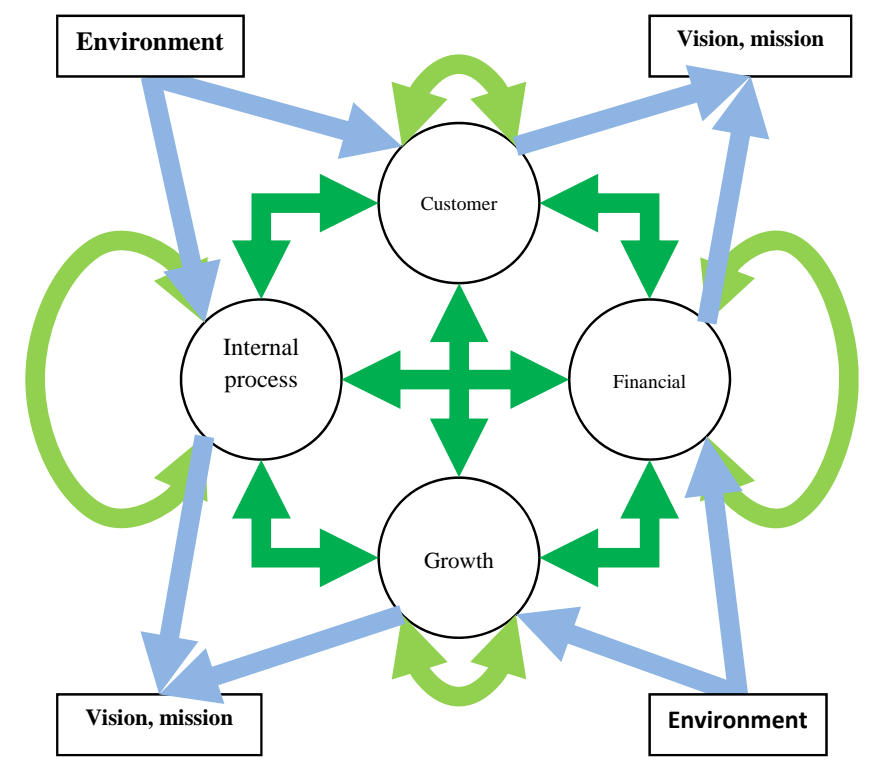

Fig.1. Relationships among different aspects of BSC

There are literally various applications of BSC, Safari Kahreh (2012), for instance, performed an empirical study to analyze customer relationship management strategy using BSC. Shojaee et al. 
(2012) presented a study to setup appropriate strategies using the implementation of balanced score card in four perspectives of customers, processes, learning and financial. They gathered important factors through three different brainstorming sessions and prioritize them using TOPSIS method. Abdolshah et al. (2012) determined strategic objectives in the strategy map of one of the best producer of electric auto part makers in Iran called Electric Vehicle Co. East and they were evaluated based on BSC perspective and they assigned appropriate values to available factors based on a hybrid method consist of analytical hierarchy process (AHP) technique with Fuzzy logic.

Hemati et al. (2012) presented a hybrid algorithm of BSC and quality function deployment to determine the criteria affecting implementation of successful outsourcing. Namazi et al. (2011) proposed an integrated framework for outsourcing using balanced score card and ELECTRE III. Azar et al. (2012) presented an empirical investigation in a case study of part maker industry using BSC method for supplier selection strategy using TOPSIS and VIKOR. Khaki et al. (2012) proposed a new method for improving efficiency of decision making units through BSC-DEA technique. Mirzamohammadi and Basirat Fard (2012) studied factors affecting productivity and the role of customer relationship management in a case study of home appliance manufacturing based on BSC method.

In this paper, we present an empirical investigation on a pipe industry using BSC method. The organization of this paper first presents details of the proposed model in section 2, while details of our findings are given in section 3 and concluding remarks are stated in section 4 .

\section{The proposed method}

In this paper, we present an empirical investigation on measuring the performance of one of Iranian pipe makers located in city of Shiraz, Iran. The proposed study designs a questionnaire based on BSC and attempts to measure the performance of this firm. The proposed study of this paper designs questionnaire and distributes among 31 managers, 94 regular employees and 110 customers of this firm during the fiscal year ended 2011. There were 12 questions associated with managers, 15 questions were related to employees and customers completed 14 questions. The questionnaire were passed to some university professor and they confirmed the questions, we have also calculated Cronbach alpha and the results were well above the minimum acceptable limit, 0.70. We have investigated the firm in terms of four BSC perspective and, for each perspective, we have considered different criteria and tried to measure the present status and deviations from desirable targets.

\section{The results}

In this section, we present details of our survey on our findings on BSC perspectives.

\subsection{Financial figures}

The first and the most important part of BSC perspective is associated with financial figures. There are three factors including revenue, cost and resources/consumptions. Table 1 demonstrates details of our findings,

\section{Table 1}

The results of forecasted and actual numbers for financial figures (Data are in Rials)

\begin{tabular}{lllll}
\hline Objective & & Forecasted & Actual & Performance \\
\hline \multirow{3}{*}{ Incomes } & Sales & $8,458,000,000$ & $3,260,205,008$ & $38.5 \%$ \\
& Profit & $27,045,500,000$ & $9,720,686,528$ & $35.9 \%$ \\
& Commissions & $1,493,800,000$ & $1,588,448,700$ & $106.3 \%$ \\
\hline \multirow{2}{*}{ Costs } & Operating costs & $7,181,000,000$ & $6,087,007,000$ & $115.23 \%$ \\
\hline \multirow{2}{*}{ Resources/consumptions } & Raw material, wages & $13,645,769,000$ & $15,924,165,480$ & $-116.7 \%$ \\
\hline
\end{tabular}


The results of Table 1 demonstrate that the proposed case study could only reach to approximately $41.4 \%$ of its targets.

\subsection{Learning and Growth}

Learning and growth includes four categories and each category consists of two to four items summarized in Table 2.

\section{Table 2}

The results of forecasted and actual numbers for learning and growth

\begin{tabular}{llccc}
\hline Objective & & Forecasted & Actual & Performance \\
\hline \multirow{3}{*}{$\begin{array}{l}\text { Product and technology } \\
\text { Development }\end{array}$} & Growth trend on technology improvement & 5 & 3.7747 & 75.4 \\
\hline Improving organizational & Update software and hardware requirements & 5 & 4.0745 & 81.5 \\
Culture & Implementation of necessary training programs & 5 & 2.84 & 56.8 \\
\hline Increase in & Employment benefit package & 5 & 3.44 & 68.8 \\
Employee job satisfaction & Job promotion opportunity & 5 & 2.93 & 58.6 \\
& Employment benefit package & 5 & 3.3 & 66 \\
& Promotion opportunities & 5 & 2.83 & 56.6 \\
& Job identity & 5 & 3.9521 & 79 \\
\hline Empowering & Management & 5 & 3.8777 & 77.5 \\
Employees' capabilities & Necessary budget for purchasing books & 4000000 & 4000000 & 100 \\
& Number of training programs & 20 & 9 & 45 \\
& Number of trained employees & 148 & 131 & 48.5 \\
\hline
\end{tabular}

As we can observe from the results of Table 2, the firm could reach up to 100 percent of its goals but there were some shortcomings especially on the number of training programs. Nevertheless, the firms could reach approximately to $71 \%$ of its learning and growth objectives.

\subsection{Internal processes}

The third component of BSC methodology is associated with measuring different internal processes' capabilities. This item has been categorized into three areas and Table 3 demonstrates details of forecasted and actual performances.

Table 3

The results of forecasted and actual numbers for internal process

\begin{tabular}{llccc}
\hline Objective & & Forecasted & Actual & Performance \\
\hline Improvement in & Job formalities & 1 & 2.68 & 46.4 \\
internal processes & Work time measurements & 1 & 1.935 & 61.3 \\
& Number of rework & 1 & 1.97 & 60.6 \\
\hline Improving safety and Security & Laws and regulation & 5 & 3.77 & 75.4 \\
within organization & Health of organization & 5 & 4.47 & 89.4 \\
\hline \multirow{3}{*}{ Organizational change } & The number of related training programs & 5 & 3.32 & 66.4 \\
& Employee motivation to upgrade educations & 5 & 3.48 & 69.6 \\
& Managers motivation for employee education & 5 & 3.00 & 60 \\
\hline
\end{tabular}

According to the results of Table 3, the proposed case study of this paper could reach about two third of the targets for most items or approximately 66\%. It seems that health of organization was the first priority where the firm reached $89.4 \%$ of its target. In addition, "job formalities” was the least priority where the firm could not reach its target.

\subsection{Customer}

Customer plays an important role for business development and we have detected five important factors influencing customers, which are summarized in Table 4 as follows, 
Table 4

The results of forecasted and actual numbers for customer perspective

\begin{tabular}{llccc}
\hline Objective & & Forecasted & Actual & Performance \\
\hline \multirow{3}{*}{ Customer satisfaction } & Being responsive & 5 & 4.33 & 86.57 \\
& Empathy & 5 & 4.33 & 86.67 \\
& Discipline & 5 & 4.63 & 92.5 \\
& Mutual trust and respect & 5 & 4.50 & 90.06 \\
& Appearance & 5 & 4.06 & 81.1 \\
\hline
\end{tabular}

According to the results of Table 4, customers are believed to be satisfied in terms of the feedback we observe and the firm reached approximately $87 \%$ of its objectives and $89 \%$ in terms of internal processes. In addition, the firm could reach $89 \%$ of its objectives in terms of customer perspectives.

\section{Conclusion}

In this paper, we have presented an empirical investigation to measure the performance of a firm, which was active in pipe production industry. There were four perspective associated with BSC framework including financials, learning and growth, internal process and customers. In terms of financial figures, the firm could reach only $41.4 \%$ of its objectives but this ratio reached $71 \%$ in terms of learning and growth,

\section{Acknowledgment}

The authors would like to thank the anonymous referees for constructive comments on earlier version of this work.

\section{References}

Abdolshah, M., Javidnia, M., Astanbous, M.A., \& Eslami, M. (2012). An integrated approach to analyze strategy map using BSC - FUZZY AHP: A case study of auto industry. Management Science Letters, 2(2), 705-712.

Azar, A., Olfat, L., Khosravani, F., \& Jalali, R. (2012). A BSC method for supplier selection strategy using TOPSIS and VIKOR: A case study of part maker industry. Management Science Letters, 1(4), 559-568.

Hemati, M., Zarei, A., Karkehabadi, H. (2012). A hybrid algorithm of BSC and QFD to determine the criteria affecting implementation of successful outsourcing. Management Science Letters, 2(2), 655-664.

Huang, H. C. (2009). Designing a knowledge-based system for strategic planning: A balanced scorecard perspective. Expert Systems with Applications, 36(1), 209-218.

Huang, H. C., Lai, M.C., \& Lin, L. H. (2011). Developing strategic measurement and improvement for the biopharmaceutical firm: Using the BSC hierarchy. Expert Systems with Applications, 38, 4875-4881.

Kaplan, R. S., \& Norton, D.P. (1996a). The Balanced Scorecard: Translating Strategy into Action. Harvard Business School Press.

Kaplan, R. S., \& Norton, D.P. (1996b). Using the balanced scorecard as a strategic management system. Harvard Business Review, 75-85.

Kaplan, R. S., \& Norton, D. (1992). The balanced scorecard measures that drive performance. Harvard Business Review, 70(1), 71-79.

Khaki, A.R., Najafi, S.E., \& Rashidi, S. (2012). Improving efficiency of decision making units through BSC-DEA technique. Management Science Letters, 2(1), 245-252.

Mirzamohammadi, S., \& Basirat Fard, F. (2012). Factors affecting productivity and the role of customer relationship management: A case study of home appliance manufacturing. Management Science Letters, 2(1), 55-66. 
Namazi, S., Barzinpour, F., \& Makui, A. (2011). An integrated framework for outsourcing using balanced score card and ELECTRE III. Management Science Letters, 1(2), 99-106.

Olson, E.M., \& Slater, S.F. (2002). The balanced scorecard, competitive strategy, and performance. Business Horizons, 45, 11-16.

Safari Kahreh, Z., Shirmohammadi, A., \& Safari Kahreh, M. (2012). An empirical study to analyze customer relationship management strategy using balanced scorecard. Management Science Letters, 2(5), 1603-1612.

Shojaee, M.R., Fallah, M., \& Fallah, M. (2012). A hybrid TOPSIS-BSC method for strategic planning. Management Science Letters, 2(8), 2845-2850.

Wang, C.H., Lu, I.Y., \& Chen, C.B. (2010). Integrating hierarchical balanced scorecard with nonadditive fuzzy integral for evaluating high technology firm performance. International Journal of Production Economics, 128, 413-426. 